
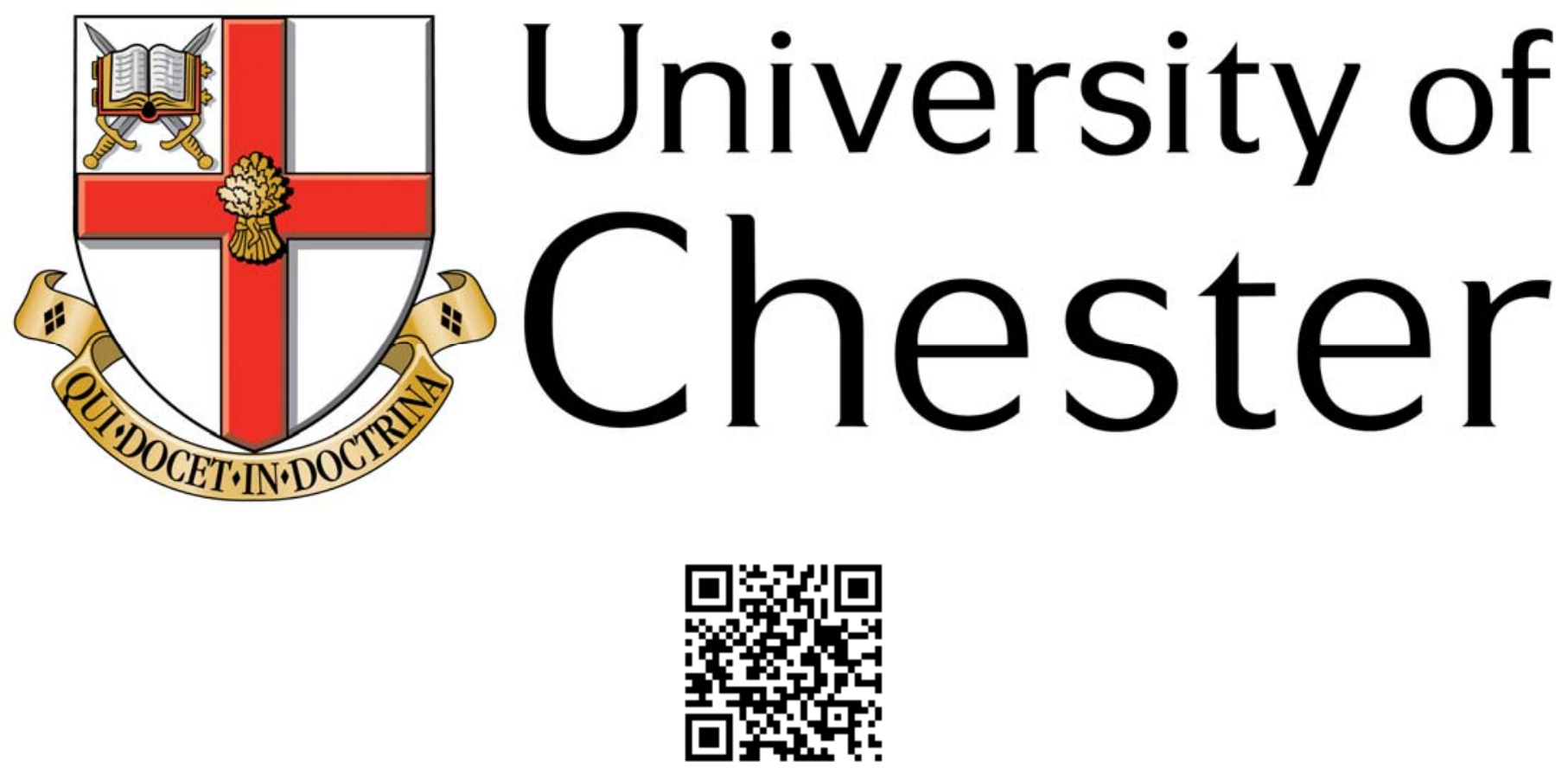

This work has been submitted to ChesterRep - the University of Chester's online research repository

\title{
http://chesterrep.openrepository.com
}

Author(s): Nicola Bugeja

Title: A motivation to move: Juxtaposing the embodied practices of Pina Bausch and Ingemar Lindh

Date: 2015. Appeared online 26 March 2015

Originally published in: Theatre, Dance and Performance Training

Example citation: Bugeja, N. (2015). A motivation to move: Juxtaposing the embodied practices of Pina Bausch and Ingemar Lindh. Theatre, Dance and Performance Training, 6(1), 3-15. http://dx.doi.org/10.1080/19443927.2014.986286

Version of item: Author's accepted manuscript

Available at: http://hdl.handle.net/10034/552346 


\section{A Motivation to Move: Juxtaposing the Embodied Practices of Pina Bausch and Ingemar Lindh}

\section{Nicole Bugeja}

\section{Abstract}

In their summer newsletter of 1996, the Centre for Performance Research (CPR) announced a workshop retreat to be led by Swedish theatre practitioner Ingemar Lindh at Druidstone in West Wales. The workshop, which was supposed to run in July of 1997, did not happen due to Lindh's untimely death in Malta a few days before. The announcement described Lindh's work as 'oscillating between sensuality, even eroticism, on the one hand, and a kind of choreography of everyday life, similar sometimes to the work of Pina Bausch, on the other' (CPR 1996, p. 9).

Taking the CPR comparison as its cue, this article investigates an overlapping concern between the tanztheater practice of Bausch and the laboratory theatre work of Lindh: that whether called 'movement' or 'action', a performer's work needs to be motivated by one's personal input (memories, thoughts, images, and other mental processes) rather than executed as an estranged and dictated vocabulary of movement. This premise was largely a result of two major influential figures in Bausch's and Lindh's careers: Rudolph von Laban and Étienne Decroux. The article starts with a concise contextualisation of a reaction to rigid methodology in both tanztheater and laboratory theatre, i.e. Bausch's and Lindh's backgrounds respectively. It then juxtaposes Laban's and 
Decroux's reflections on embodied practice, leading the way to a discussion of the matter in the practices of Bausch and Lindh. To achieve broader understanding, the juxtaposition is supported by a close reading of Rick Kemp's (2012) and Erika Fischer-Lichte's (2008) accounts of 'embodied mind'.

Keywords: embodiment of mental processes, Laban, Decroux, Bausch, Lindh

\section{A Reaction to Rigid Methodologies}

Despite indicating a similarity in 'a kind of choreography of everyday life' (CPR 1996, p. 9), the CPR announcement does not actually imply a strong resemblance between the practices of Bausch and Lindh. To do so would have been, to say the least, a far-fetched assumption, seeing that the two practitioners were not in contact with each other's work and an aesthetic influence was highly unlikely. Bausch having become internationally renowned and influential, and Lindh having never reached such fame status, it would have been more likely for the Swedish practitioner to be influenced by Bausch. Operating within a very detached laboratory context, however, Lindh never got to witness any of Bausch's work. ${ }^{1}$ In

1 By the term 'laboratory theatre' I refer to the activity that was triggered in the early years of the twentieth century and whose main innovator, Konstantin Stanislavsky, described as 'the actor's work upon oneself' (Stanislavsky 1963) - a process which tends to present more questions than absolute answers, and as such induces a continuous, open-ended research. Within a laboratory theatre context, actor training, performance, and the day-to-day life became a personal responsibility for each actor, rendering the practice reminiscent of spiritual or self-development contexts not unlike a monastic order, or the master-apprentice communal learning systems of Asian dance-drama traditions (Savarese 2010, pp. 225-227). For a detailed discussion of laboratory theatre see Schino (2009). 
view of this, I contend that rather than a question of aesthetic and dramaturgical style, what makes the work of Bausch and Lindh comparable in 'a kind of choreography of everyday life' (CPR 1996, p. 9) is more their reaction against rigid structures of performance productions like the set movement vocabulary of classical ballet or fixed directorial montage. Both practitioners challenged such structures, eventually leading performers to focus on personal motivations for movement, and gradually developing a practice of embodiment specific to each and every performer. In view of his lesser known profile, it is pertinent to provide a brief context of Lindh's work prior to further juxtaposition to Bausch's practice.

Lindh was born on 21 February 1945 in Gothenburg, Sweden. Following his initial theatre experiences at a theatre school (Skara Skolscen) as well as jobs at the municipal theatre in Stockholm, he enrolled at the National Academy of Ballet (Stora Teaterns Ballettskola of Gothenburg and Ballettakademien of Stockholm). From 1966 to 1968 he was an apprentice and also assistant of the corporeal mime master at L'Ėcole de Mime of Étienne Decroux in Paris. In 1968 he came upon the work of Jerzy Grotowski and due to his and other students' desire to study with the Polish master, he was expelled from the school by Decroux. The incident disrupted the performance-demonstration Research Scientists in a Laboratory that Decroux had been developing with his group of advanced students, or 'anciens' (Sklar 2002, p. 135). ${ }^{2}$ While the mime master tried to recover the situation by inviting Lindh, Maria Lexa, and 
Gisèle Pélisson to return to the school, they all stuck by Yves Lebreton whom Decroux refused to accept back. Following this episode, the four exstudents of Decroux founded Studio 2 in 1969, 'the first professional mime troupe in Scandinavia' (Watson 1993, p. 6). They were eventually hosted by Eugenio Barba at his Nordisk Teaterlaboratorium in Holstebro, Denmark. After the work with Studio 2, and also following a period of time in Stockholm as a teacher at Teaterstudio and then as head of the Mime Faculty at the State School of Dance, Lindh founded his laboratory theatre, the Institutet för Scenkonst. ${ }^{3}$

Lindh (1995, p. 66) considered his practice to be 'a kind of crossroad[s]' between the work of Decroux and of Grotowski. However, despite being equipped with such valued apprenticeship, he still wanted 2 In this paper, I consider Decroux as forming part of the laboratory theatre tradition. A main reason why Decroux might arguably be placed beyond the defining limits of laboratory theatre is the fact that he developed a codified approach to the body - corporeal mime - that one could view as too much of a concentrated effort upon one genre. However, as Marco De Marinis (2004, pp. 37-38) points out, one should refrain 'from thinking of corporeal mime as something that can be contained in a single formula that could be defined once and for all. [There are] several levels within [Decroux's] artistic and pedagogical research in the area of corporeal mime'. This indicates that although Decroux focused his life-time career on corporeal mime, he conducted as much research as his contemporaries who sought to work beyond one style of theatre. Also, he belonged to the French lineage of laboratory theatre having been particularly influenced by Jacques Copeau. Like other laboratory practitioners, he insisted on addressing performing as a vocational practice and also adopted the masterapprentice teaching approach within his low-profile basement school in Paris. The processual refining of corporeal mime was for him more important than producing economically successful performances, and he also used improvisation as a training medium, wanting to discover new approaches to the actor's craft.

3 In its fifth decade of existence, the Institutet is today situated in Sweden on the outskirts of Gothenburg. 
to liberate himself from his heritage and not get stuck in repetitions of what he already knew. This is illustrated mainly in his views on precision. He argued that laboratory theatre practitioners like Stanislavsky, Copeau, and Decroux undertook an assiduous search for precision. He called Decroux's a "'perfect" technique, accurately thought out on the practical and theoretical level [and] equipped with a poetic power that is overwhelming. What is already perfect cannot be subsequently developed' (Lindh 2010, p. 22). With this belief, Lindh resisted fixed performance structures (such as choreography and directorial montage) that sought to acquire precision. Inspired by the actual everyday life dynamic that things change despite efforts to fix them, he opted instead for collective improvisation as performance via 'mental precision'.

Frank Camilleri (2010, p. 220-221) explains 'mental precision' as indicating 'the quality of the movement of the mind that precedes the physical manifestation of action. [It] does not imply a predominance of mind over body. The status of action-in-the-mind implied by 'mental precision' [...] is indeed that of physical action'. I will discuss 'mental precision at a later stage. For now it suffices to establish that Lindh's 'mental precision' marked the actor's attempt to be highly aware of and embody his mental processes, as opposed to fixing one's physicality. ${ }^{4}$ Furthermore, Lindh placed such embodiment as an actual improvised mode of performance in itself. Although not as an improvised mode of performance, Bausch also led her dancers to embody their personal 4 For a more detailed discussion of Lindh's 'collective improvisation' and 'mental precision' see Camilleri (2008a). 
motivations for movement rather than follow the given vocabulary and storylines of ballet. In this paper, I view personal motivations for performing as a wide spectrum of phenomena including one's thoughts, emotions, sensations and memories, or what Kemp (2012) calls 'mental processes'. Kemp addresses such mental processes as cognitive, biological phenomena operating in a continuum where they induce action and are also affected by it. He argues that 'the mind is inherently embodied, not just in the sense that the brain operates in a body, but because physical experience shapes conceptual thought, and thought operates through many of the same neuronal pathways as physical action' (Kemp 2012, p. xvi). In line with Kemp, whenever I mention 'mental processes' in this paper, I mean to address them as embodied phenomena in a process where they are both triggering a performer's work and also being informed by it. I will discuss this further on in the paper. For now this explanation suffices to present my argument that both Bausch and Lindh led their performers to embody their personal mental processes as both a means of performance production and aesthetic in itself.

Such a more personalised approach to performance was, to a great extent, the result of a reaction (pervading the twentieth century) against rigid methods of performance production within both practitioners' backgrounds. In fact, despite having never witnessed each other's work, due to the cross-fertilisation of practices happening throughout the twentieth century, Lindh and Bausch were, on a widespread level, essentially operating within comparable, if not similar, influences. In effect, tracing the influences of Decroux's corporeal mime and its 
connection to dance practices, Lebreton (2012, p. 285) presents interesting cross-influences between twentieth-century laboratory theatre and modern dance. The genealogy he traces indicates that both Lindh's and Bausch's lineages go back (directly or indirectly) to the work of the French acting teacher François Delsarte, and one may say that the subsequent influence was that of embodied mind. Delsarte is mostly known for the acting style he developed, attempting to connect the actor's emotional experiences with a codified set of gestures and movements:

The core of his theory states that there is a connection between mental attitudes, emotions, physical postures and gestures. According to this, one's emotional state would be communicated through one's physical appearance and performance $[\ldots]$.

Practicing those positions would reinforce the feelings they traduce and all emotions would have their own bodily translation (the gesture would reinforce them and at the same time they would reinforce the gesture).

This postulate coincides with the famous modern dance principle according to which the intensity of a feeling determines the intensity of a gesture, in opposition to the classical dance rule that makes use of codified gestures which are (presumably) not related to the mental state of the dancer. (Contemporary-dance 2012, my emphasis)

Central to Delsarte's practice, therefore, was the connection between one's movement and the corresponding mental states, a connection which was to be researched with further rigour by later practitioners. Besides 
this link in genealogy, Bausch and Lindh were also aware of each other's general contexts. ${ }^{5}$ During the early work with Tanztheater Wuppertal, Bausch tapped into her previous dance training but also embraced European and American theatre traditions, including Antonin Artaud, Grotowski, Tadeusz Kantor, and Peter Brook. She must have also witnessed the work of the Living Theatre (Climenhaga 2012, pp. 9-10). This shows that just as Lindh was aware of contemporary dance practices (especially from his dance training) before he founded the Institutet, so was Bausch aware of theatrical experiments. Both practitioners' backgrounds, i.e. tanztheater and laboratory theatre, were reacting against rigid and overused methods of performance production. In needing alternative ways of dancing and acting, both contexts were pushing towards a more personalised effort from actors and dancers.

Within the context of laboratory theatre, the reaction against rigid methodology entailed a shift in focus from the author's text to the actor's creativity and was given a huge impetus by Vsevolod Meyerhold mainly through the use of improvisation. ${ }^{6}$ With the focus transferred to the actor,

5 Delsarte's approach became increasingly popular and was particularly influential in America where it was often misinterpreted. Consequently, the method degenerated into stale melodramatic posing, the kind which Stanislavsky and others often criticised. However, he contributed valuable ideas to the field, such as the notion that there is a mutually exclusive track of influence between gestures and mental processes, a premise that both Bausch and Lindh built upon.

6 For a detailed discussion on Meyerhold's reaction against the dominance of the author's text, and on his effort to grant actors more agency via improvisation see Leach (2003). 
an important matter re-emerged, which for laboratory theatre is still a core research area, i.e. embodiment. It is apt to refer to Fischer-Lichte's (2008, p. 78) argument on the matter. She states that primarily prior to the twentieth century, audience members were expected to 'empathise exclusively with the dramatic character', and if they paid attention to the actors' 'phenomenal body' they would disturb the illusion of the fictional environment depicted on stage. Fischer-Lichte further argues that at the beginning of the twentieth century and its primary focus on the actor, practitioners were no longer satisifed with expressing textually predetermined meanings. They were not ready to comply with a system which disembodied the actor of his corporeal materiality and which demanded that he embodied a fictitious identity. On the contrary, they wanted to train the actor to transmit meanings via one's 'malleable' body:

The actor's effect on the spectators no longer depended on the spectators' ability to de-code signs given in the actor's movements; it was now presumed that the actor's malleable body itself had an immediate effect on the body of the spectator. Previously the actor's movements were designed to translate meaning laid down in the literary text. Now they served as a stimulus to induce excitement in the spectators and/or motivate them to generate new meaning themselves. While the first enlisted performativity in the service of expressivity, it was now seen to possess an energetic, affective potential. (Fischer-Lichte 2008, p. 81-82)

Meyerhold's various biomechanic exercises, for instance, were not created to transmit meanings embedded in an author's dramatic text, but to 
present the body's kinaesthetic potential. Here, the accentuated materiality of the actor made it possible for the audience members to interpret new meaning from what they perceived.

In the 1960s, particularly with Grotowski's and Barba's laboratories, there was increased reference to the body's materiality. Practitioners, however, did not address the body as a totally malleable and controllable material. Fischer-Lichte exemplifies her argument with Grotowski's use of the dramatic text. For Grotowski, performers do not serve the purpose of embodying a character, nor are they 'malleable' material:

The role no longer constitutes the ultimate goal of the actors. Instead, their bodies themselves appear as something spiritual, mental - as embodied minds. [...] The actor no longer lends his body to an exclusively mental process but makes the mind appear through the body, thus granting the body agency. [...] The body does not represent a tool - it is neither a means for expression nor material for the creation of signs. Instead, its 'material' is 'burned' and converted into energy through acting. The actors do not control their body - neither in [the eighteenth century] nor Meyerhold's sense - they rather turn it into an actor itself: the body acts as embodied mind. (Fischer-Lichte 2008, p. 82)

With the return of interest in laboratory theatre during the second half of the century, therefore, the actor was not addressed any more as containing the thought processes trigerred by an author's text, or featuring a malleable virtuoso body of the actor. Actors became trained, rather, in a holistic approach, i.e. being aware of their mental processes 
and simultaneously in control of the resultant physicality. Not only were the actors not meant to express a foreign thought process (that of the character) or to use their bodies as an estranged plastic medium, but they were actually invited to embody their own personal mental processes. Together with other reforms, embodiment has been, and still is, a fundamental aspect of laboratory theatre, and was the main field of research for Lindh's development of 'collective improvisation' via 'mental precision'.

Similar to the theatre reforms that happened towards the beginning of the twentieth century, when practitioners reacted against the overbearing power of the author's text and to stagnant approaches to acting, dance underwent various radical changes. In reaction to the rigid vocabulary of classical ballet, where dancers were technical virtuosos but barely contributed anything personal, practitioners sought freer ways of dancing which embraced individual expression. What influenced Bausch's tanztheater to eventually emerge, in fact, goes back to early modern dance pioneers who created new approaches to dance in both Europe and America in the first half of the twentieth century. ${ }^{7}$ In effect, when speaking of tanztheater which flourished in the 1960s, it is necessary to mention an earlier dance movement from the first decades of the century, i.e. Ausdruckstanz, which followed the influence of modern dance pioneers

7 This is not unlike the development of laboratory theatre, where practitioners in the second half of the century revived the work of the reformist directors of the first half. 
Isadora Duncan and Loïe Fuller. ${ }^{8}$ Bausch, who revived tanztheater in the 1960, could not have developed her work without the ausdruckstanz movement and its resistance to classical dance styles. Her 'everyday' themes could only be accepted after the early twentieth-century introduction of 'everyday' movements in choreography. At the time, the observation of everyday life liberated dance from the limits of technique and made it possible for dancers to express (ausdruck) their personal experience. With the emphasis that movement should reflect, or be the embodiment of, one's mental processes, practices of dance and theatre started to overlap much more, hence the emergence of genres such as tanztheater. Such overlap is strongly evident in the work of Laban and Decroux. Both practitioners sought to imbue movement with the performers' individual mental processes, rather than having them follow rigid vocabularies in an alienated manner. Within such practices of embodiment, it did not matter much if they referred to their work as 'action' or 'movement', 'theatre' or 'dance'.

\section{Between Laban and Decroux}

Decroux's and Laban's working life overlapped, yet, the practitioners never had any direct contact. Thomas Leabhart (2007, p. 71), an exstudent of Decroux, mentions an indirect link which indicates the corporeal mime master's possible knowledge of Laban and his students.

8 Meanwhile, in America, Ruth St Denis and Ted Shawn were also creating new dance practices, eventually influencing the dance approaches of two of their company members, Doris Humphry and Martha Graham (Climenhaga 2012: p. 194). 
He writes that Decroux saw Kurt Jooss' signature ballet The Green Table in Paris in 1932: 'A tantalising mixture of drama - abstracted design (archetypes in characterisation), and militant politics - The Green Table marked Decroux, who, thirty years later, still spoke of it fondly'. Despite the lack of direct contact, however, Decroux's corporeal mime and Laban's modern dance practice had much in common - primarily the drive to discover a new and wider range of body movement possibilities. They both worked extensively on the body in an analytical and methodical way, trying to free movement from rigid techniques. Through this reaction to conventional vocabularies such as classical ballet, they both worked on disequilibrium, counter tensions in the performer, and the focus on the torso rather than on the peripheral limbs (De Marinis 1993, p. 115). In this search, they used aspects from both art forms of theatre and dance in line with their vision of a holistic performing artist. Thinking beyond classical ballet's set vocabulary of movement Decroux viewed the body as a 'keyboard' (Leabhart and Chamberlain 2009, p. 5). On a comparable level, Laban considered the body like an artist's 'palette' (Bradley 2009: 30). Both metaphors suggest that performers need to know their bodies well in order to achieve a wide range of movement combinations, which would extend one's performative possibilities.

Considering these affinities between the two masters, it is important to point out that Decroux's blatant criticism of dance in Words on Mime (1977) was not specifically aimed at modern dance but at classical ballet. Decroux's relationship to classical ballet, in fact, was always contradictory and controversial. While he continuously criticised the form and pointed 
out its difference from corporeal mime, numerous exercises he devised for his practice were based on principles and positions of classical ballet. What attracted him to it (rather than to modern dance), was its codified nature and very rigorous grammar. He thus appreciated its technical discipline and made use of it, but ultimately disliked it as an art (De Marinis 1993, p. 112). He considered classical ballet as too 'abstract', and like the modern dance reformists of the early twentieth century, he did not appreciate its dependency on music. On the other hand, he viewed mime as 'concrete' and based on life: while a classical dancer deals with symmetrical models, exact repetitions, and regular rhythms as demanded by the music, the mime works with asymmetry, variation, rhythmic models of language, and natural movements of the body. The freedom from the dominance of music, as well as the priority given to the natural dynamics and rhythms of the body are thus common to both Laban and Decroux. Furthermore, like Laban and other modern dance pioneers, Decroux did not appreciate the air-bound and light nature of ballet, preferring the weightier and grounded corporeal mime with its resemblance to the heavier effort of manual work. For him, dance is 'serene' while mime is 'unhappy' and 'anxious' (De Marinis 1993, p. 140). The tragic notion that Decroux associates with mime is not a question of psychological states. He refers, rather, to the physical effort (suffering) entailed by the centrality of the trunk in corporeal movement.

Besides all these common factors between Decroux's and Laban's perception of movement, what is of most interest to this discussion is that their separate analytical study of movement was not an end in itself, but a 
vehicle to manifest a performer's mental processes. Decroux emphasises that a mime's movement is always accompanied by thought, a factor which for him distinguishes it from classical dance:

It's not possible to resolve a problem you're faced with while dancing; if one has a difficulty to resolve, one feels like sitting down and thinking. [...] Dance isn't dramatic. And when, under the name of dance one does drama, it's because it's not dance. And so what is dance? What are its depths? What do I think of when I say dance? [...] When you dance, there's no question that you have to do so intentionally, and yet you feel that dance carries you away. You make a decision to dance, of course, but you dance a bit in spite of yourself. (Decroux 2009, pp. 114-119; emphasis in the original)

Decroux here explicitly argues that classical ballet dancers move 'in spite of' themselves because they follow a set vocabulary of movement. ${ }^{9}$ On the other hand, in corporeal mime (as in modern dance), performers move in tandem with their mental processes (in Decroux's words 'intentionally'). He explains the matter further by arguing that, unlike mime, dance repeats itself, and exemplifies his argument with the act of striking a nail 9 Joseph Roach (1985, p.91) shows that even practitioners from within the ballet tradition itself, such as Noverre, felt dissatisfaction with automatic movement: 'Although he [Noverre] cheerfully compared the ballet d'action to a machine in which the dancers are cogs, the solitary spectacle of purely mechanical technique left him cold: "When these parts [arms and legs] are managed without genius, when [the dancer] does not direct these different motions, and animate them by the fire of sentiment and expression; I feel neither emotion nor concern. The dexterity of the dancer obtains my applause: I admire the automaton, but I experience no further sensation"'. 
with a hammer. He says that a factory worker never repeats the same movement twice: first he hits and makes the nail penetrate the wood; then he hits again to make the nail penetrate the wood deeper, and so on. He states that this is not repetition, but movement imbued with the necessary force per strike, which is the mime's objective. Decroux believed that the actor's task is to link physical work with images, which would render the right tension in the body. He argues that 'the work of the actor consists in imagining what doesn't exist. [He] has to be thus able to imagine a wagon that he intends to push or pull' (Decroux 2009: 143). Embodying one's mental processes, then, does not necessarily mean one's intimate thoughts or emotions, but also a given image. The point is for performers to be highly aware of (and not alienated from) their mental processes.

In his analysis of movement, Laban did not perceive movement for movement's sake either, but was specifically interested in its 'content, meaning and relationship to the human spirit. He was not concerned with the embodiment of music [...]; he preferred [...] movement that was expressive' (Bradley 2009, p. 47; my emphasis). Laban's performer, in fact, also brings one's mental processes into the practice, and like Decroux's mime, does not repeat automatically but is aware of the tension placed in each movement. Karen Bradley's explanation of Laban's reflections sounds uncannily similar to Decroux's:

Inner tension, outwardly expressed makes the performance alive and real. As an experiment, if one moves one hand forward in space, as a gesture, 
but the movement has no tension at all, no drama, nothing is revealed except direction and rate of movement. Add a countering tension from the stomach, or the heart, and meaningfulness appears. [...] Laban asked: “Which are the elements of theatrical art?" He answered himself: That the essence of mime is the gift and the art to express thoughts, feelings and volitions through bodily movements. (Bradley 2009, pp. 39-44; my emphasis)

Laban and Decroux, therefore, are on parallel levels when they emphasise that the performer needs to work on mental processes ('thoughts', 'feelings', 'volitions') that get manifested as tension in the body - tension that creates theatricality.

In this respect, both Laban and Decroux talk of 'movement' in the same way in which later theatre laboratory practitioners, particularly Grotowski, spoke of 'action'. Grotowski's work, especially the first phase (Theatre of Productions, 1957-1969) and the last one (Art as Vehicle, 1986-1999), was based on the premise that an action needs to be informed by a specific intention:

According to Grotowski, impulses are linked to the right tension. An impulse appears in tension. When we in-tend to do something, there is a right tension inside, directed outside. Grotowski touched upon the question of intention in his conference at Liège in 1986:

'In/tension - intention. There is no intention if there is not a proper muscular mobilisation. This is also part of the intention. The intention exists even at a muscular level in the body. [...] Usually, when the actor thinks of 
intentions, he thinks that it means to pump an emotional state. It is not this. Intentions are related to physical memories, to associations, to wishes, to contact with the others, but also to muscular in/tensions.' (Richards 1995, p. 96; emphasis in the original)

Grotowski emphasised that if a physical action is not imbued with a performer's relation to personal memories, associations, or wishes, it turns into a 'conventional gesture', i.e. often belonging to an already established vocabulary. Such a distinction becomes pertinent when comparing, for instance, foxtrot dancing to a physical structure within Grotowski's laboratory theatre; the latter is based on physical action connected to an image or association (in Kemp's terms, a mental process), whilst the former is based on the technical particularities of style conventions. The performer works in association with some kind of image, whilst the foxtrot dancer does not.

Operating within the expressionist modern dance movement and against fixed vocabularies, Laban also speaks of the necessity that a movement is driven by an intention. Consequently, the practitioners discussed here are speaking of a specific amount and dynamic of tension being manifested in the body, irrespective of whether that manifestation is called 'action' or 'movement'. Moreover, they believe that different tensions manifest in the body are already theatrical in themselves, even without being given further semantic meaning through other media. Decroux, for instance, states that 
man carries a drama within himself long before being in conflict with another man: he would like it if one thing could offer everything; he'd like to be able to go to the left while going to the right. The body alone recounts this drama. (Decroux 2009, p. 112)

Similarly, Laban spoke of 'Effort' as a kind of inner attitude towards the four dynamics of weight, space, time, and flow. According to Bradley

Laban meant that through the exploration of various combinations of Effort characters will be both consistent and clear. [...] [F]or example, a character who arises out of hastening directness might have an encounter with a character who finds that he/she is avoiding the first character and becoming bound and sustained. Dramatic possibilities arise! (Bradley 2009, pp. 32-39)

In this sense, if the body is imbued with the required tension, there can be no such thing as an 'empty' gesture or a clear-cut definition of whether the performer is dancing or acting. The next section discusses how this movement analysis of Laban (via Jooss) and Decroux is reflected in that of Bausch and Lindh.

\section{Between Bausch and Lindh}

Developing beyond their masters' work, both Lindh and Bausch focused on the embodiment of mental processes, including thoughts, emotions, memory, and images, as both a tool for performance creation and as an aesthetic in itself. As a result of this focus, each performer gave a distinct 
contribution, and both practitioners' work necessarily operated beyond an author's linear narrative or realistic aesthetic. Royd Climenhaga (2009, p. 2) explains that in Bausch's context: 'no longer are we telling a theatrical story through dance movement or playing out characters in a drama through physical action. The theatricality of the moment is enacted on the bodies of the performers themselves'. It is within a similar context that Lindh states: 'the actor has no message - he is the message' (Lindh 1995, p. 15).

When Bausch started directing the Tanztheater Wuppertal she did not follow the linear narrative of the ballet or opera she was producing, but extracted the most essential image from it. Her dancers used that extraction as a source from which their work could develop (a source which triggered associations, memories, images, thoughts and other mental processes), knowing that they could express it in different ways, not necessarily bound to a set vocabulary of movement. However, performances (such as the two operas by Christoph Willibald Gluck, Iphigenia in Tauris [1974] and Orpheus and Eurydice [1975]), were still based on the ballet or opera as the main driving agent of the work. This changed when Bausch demanded of her dancers that they bring more of their individual life into the work. For instance, in preparation for The Seven Deadly Sins (1976) and Don't Be Afraid (1976), she asked for the performers' own feelings, rather than those of characters in the story of the ballet or opera. Climenhaga argues that here 
Bausch was beginning to uncover [...] the motivating impulse from which movement begins, and that impulse is always a person in a specific situation. [...] The structure is still built upon a dance ground, but is starting to be expressed with the representational methods of the theatre, and the dancer is allowed to show personal openness beyond the degree of her turnout. [...] It is this revelation of subjective experience in Bausch's pieces - derived from and represented through the dancer's body - that is the basis for tanztheater and that provides its break from dance. (Climenhaga 2009: pp. 13-14)

Bausch, therefore, broke free from dance conventions by initiating the performance process from the personal motivations of her own dancers, rather than starting off with formal steps of a known technique. She did apply elements used by 1960s' American dancers (including collage, pedestrian movement, and repetition), but focused on the subject matter expressed through her performers' individuality, rather than just on the movement form. This also explains Bausch's famous statement about her performers: 'I'm not so interested in how they move as in what moves them' (quoted in Schmidt 1984, pp. 15-16).

Bausch developed tanztheater into a mature style with the performance Bluebeard (1977), where the central means of expression was no longer movement derived from the ballet or opera theme. In this case, rather than asking performers for individual expression in relation to ballet or opera themes, she started the process by asking them questions about themselves. At this point, the inter-relationship between the dancer's mental image and resultant movement grew, and it became 
more evident that that movement was the performer's personal input. Interestingly, here Climenhaga refers to the dancer's work in terms of 'gesture':

Gesture is more inclusive than a simple movement, and becomes a complete action, often with underlying intent. This approach necessarily brings in dramatic potential, and operates along the lines of Bertolt Brecht's idea of Gestus. In German, Geste is more simply defined as 'gesture', whereas Gestus incorporates a feeling that is more replete, more full of the intent from which the action derives. (Climenhaga 2009, p. 116; emphasis in the original)

Climenhaga's difference between 'movement' and 'gesture with underlying intent', recalls the discussion in the previous section. Climenhaga speaks of 'movement' when referring to the first few years of Bausch's direction of Tanztheater Wuppertal, where she abandoned the narrative structure, but dictated the theme and choreography to her dancers. On the other hand, he speaks of 'gesture' to refer to movement that emanated from the performers' individual and personal mental processes.

To get to this point, Bausch used choreography principles to structure the performance material, but resorted to theatre direction to work on the dancers' individual contribution. Climenhaga argues that this

is an inversion of the traditional structure of story ballets, for instance, that use a movement-centred language to tell a theatrical story. In this case, we 
take moments of theatrical presence, and put them together through dance construction principles. [...] Instead of being built on the dancer's body as empty vessel to execute the movement, the structure is built on the personal investment of the dancers. [...] The dancers do not re-present experience bodily, but begin the process whereby bodily experience is made present. That realigned attitude towards the performer's body on stage provides a base for a new approach to performance and creates an alternative to either illusionistic practice in theatre or abstract movement for movement's sake in dance. (Climenhaga 2009, pp. 57-92)

Bausch's mature period of tanztheater, particularly through its employment of presentation (rather than representation) and the resultant self-reference of the performer, thus exemplifies Fischer-Lichte's argument that 'the mind does not exist in opposition to the body. Rather, the mind finds its existential ground in the body, which brings it forth and can thus appear as embodied mind' (2008: 173; my emphasis). It is this expressive nature of tanztheater with its embodiment of the dancer's individual mental processes which makes Bausch's work comparable to Lindh's in a 'kind of choreography of everyday life'.

Throughout his long-term research on collective improvisation as performance, Lindh managed to develop a kind of mindfulness meditation process in which the performers nurture a heightened awareness of what is arising within them (i.e. their mental processes and the resultant apparent physicality) and outside of them (i.e. the whole environment including colleagues and audience). He called this heightened awareness 'listening' to one's 'social situation', and more particularly, he called the 
awareness and observation of one's mental processes 'mental precision' (Lindh 2010). For him, the precision in the actor's apparent physicality was only the present moment causation of 'mental precision' and, as such, was never fixed or choreographed. It was through this heightened awareness of their arising mental processes and to what was happening in their environment that Lindh's performers improvised the performance itself. His reference to dance was intended to develop this research.

Lindh worked in relation to dance mainly after the period and performance of Frescoes (1979). This is most evident in his research on 'dans-träning', where rock music was used to inspire an uninterrupted flow of energy. It is at this point in Stepping Stones (2010) that Lindh provides his main reflections on dance. These often echo both Decroux's and Grotowski's opinions on the matter, and also resonate with Bausch's work on 'gesture'. I quote Lindh in full as his reflections shed important light on this discussion:

For the first time ever, we made use of a clear external stimulus in order to leave the greatest possible freedom to the actors. We utilised recorded music as a dynamo-rhythmical reference point and called this work dansträning (dance training). The first task proposed to the actors was to explode in the greatest, strongest, and fastest way possible. This was done to avoid the possibility of deliberately controlling the movement that could again 'imprison' the energy. Another task was to not let the music 'do' all the work; that is, not to allow the actor's level of energy to remain below that of the music. The use of music was not aimed at creating an atmosphere or dramatic expression, but to serve as a superficial impulse 
and as a reference for dynamics. Naturally, this situation resembled dance in a surprising manner. So the first thing that needed defining was the difference between a dance step and an action, between a movement and an act. The moment we call something 'dance' we need to know what we understand by the term. (Lindh 2010, pp. 85-88; emphasis in the original)

As with modern dance practitioners, Lindh did not want his actors to be completely led or controlled by music. When realising that the work 'resembled dance' he felt that he immediately needed to distinguish between a movement and an act. Like Grotowski, for him a gesture or a step has to have inherent value, rather than just form part of a sequence of movements. Like Decroux, he states that a single movement cannot be considered as dance, since dance necessitates repetition: 'It is difficult to recognise a waltz, a tango, or a polka in only one step because steps or movements in general exist exclusively as means and not as an aim or a value in itself' (Lindh 2010, p. 87). This observation led him to introduce the principle that every movement performed by actors had to be imbued with its own value, 'a theatrical act which could exist by itself. In doing so we obtained a new type of energy in our work. [...] We began to combine the work on intention with dans-träning and create what we called 'dance etudes' (Lindh 2010, p. 87). As with Decroux, therefore, Lindh's discrimination was not towards expressionist modern dance but towards genres that have a specifically set movement vocabulary, and which do not engage the performer holistically. Examples are tap dancing or waltz forms that employ repetition, and where dancers apply the specific 
vocabulary, irrespective of their mental processes. In creating dance etudes and imbuing every movement with an intention, Lindh came very close to Laban's emphasis that every movement needs to be informed with the right tension. In effect, although Grotowski, Decroux, and Laban differentiated between the terms 'movement' and 'action', in practice, they were all seeking to manifest in-tension - tension/effort in the body. It is not surprising, therefore, that Lindh quotes Henry Moore in his chapter called Frescoes: 'It is not an action that is drama, it is tension - that something could happen' (Lindh 2010, p. 22; emphasis in the original).

\section{Conclusion}

Not much has been published about Lindh and his research on collective improvisation as performance. A statement such as the CPR comparison of Lindh's work to that of Bausch, thus, comes as tantalising food for thought in an understudied and aridly documented field of research. I thus tried to deal with the CPR announcement as a clue, letting it lead me to prod deeper into Lindh's work.

As such, I have traced links between Bausch's and Lindh's artistic contexts, i.e. tanztheater and laboratory theatre respectively, and briefly discussed how both constituted a reaction to rigid methodologies, promoting a more personal contribution from each performer. I closed in on this context via a juxtaposition of Laban's and Decroux's reflection on the importance of embodied practice. This led me to the final juxtaposition of Bausch's and Lindh's work on the embodiment of one's 
personal mental processes as both a tool for creation and as an actual dramaturgical aesthetic. Finally, I concluded that it was this reference to the performer's personal motivation that triggered the CPR comparison of Lindh's work to that of Bausch.

\section{References}

Bradley, K., 2009. Rudolf Laban. London and New York: Routledge.

Camilleri, F., 2008a. Collective Improvisation: The Practice and Vision of Ingemar Lindh. The Drama Review, 52 (4), 82-97.

Camilleri, F., 2008b. 'To Push the Actor-Training to its Extreme': Training Processes in Ingemar Lindh's Practice of Collective Improvisation. Contemporary Theatre Review, 18 (4), 425-441.

Centre for Performance Research Newsletter. 1996 (Summer).

Climenhaga, R., 2009. Pina Bausch. London and New York: Routledge.

Climenhaga, R., 2012. The Pina Bausch Sourcebook: The Making of Tanztheater. London and New York: Routledge.

Decroux, E., 1985. Words on Mime, trans. M. Piper. CA: Mime Journal.

Decroux, E., 2009. The Decroux Sourcebook, ed. T. Leabhart and F. Chamberlain. London and New York: Routledge.

De Marinis, M., 1993. Mime e Teatro nel Novecento. Firenze: La Casa Usher.

De Marinis, M., 2004. Decroux: Why a Theatre Laboratory? In Odin Teatret, eds. Peripeti: Why a Theatre Laboratory. Aarhus: Odin Teatret.

Fischer-Lichte, E., 2008. The Transformative Power of Performance. London and New York: Routledge. 
Kemp, R., 2012. Embodied Acting: What Neuroscience Tells Us About Performance. London and New York: Routledge.

Leabhart, T., 2007. Etienne Decroux. London and New York: Routledge.

Leabhart, T. and Chamberlain, F., 2009. The Decroux Sourcebook. London and New York: Routledge.

Leach, R., 2003. Stanislavsky and Meyerhold. Bern: European Academic Publishers.

Lebreton, Y., 2012. Sorgenti: Nascita del Teatro Corporeo. Pisa: Titivillus.

Lindh, I., 1995. Gathering Around the Word Theatre. In P. Paavolainen and A. Ala-Korpela, eds. Knowledge Is a Matter of Doing. Helsinki: Acta Scenica, pp. 58-80.

Lindh, I., 2010. Stepping Stones. Holstebro, Malta, and Wroclaw: Icarus Publishing Enterprise.

Richards, T., 1995. At Work with Grotowski on Physical Actions. London and New York: Routledge.

Roach, J., 1985. The Player's Passion: Studies in the Science of Acting. Michigan: University of Michigan Press.

Savarese N., 2010. Eurasian Theatre: Drama and Performance between East and West from Classical Antiquity to the Present. Holstebro, Malta, and Wroclaw: Icarus Publishing Enterprise.

Schino, M., 2009. Alchemists of the Stage: Theatre Laboratories in Europe, trans. P. Warrington. Holstebro, Malta, and Wroclaw: Icarus Publishing Enterprise.

Schmidt, J., 1984. Pina Bausch: A Constant Annoyance. In N. Servos and G. Weigelt, eds. Pina Bausch Wuppertal Dance Theatre or The Art of Training a Goldfish. Cologne: Ballett Bühnen-Verlag, pp. 13-16. 
Sklar, D., 2002. Etienne Decroux's Promethean Mime. In P. B. Zarrilli, ed. Acting $(R e)$ Considered - A Theoretical and Practical Guide - second edition. London and New York: Routledge, pp. 129-39.

Stanislavsky, K., 1963. Il Lavoro Dell'Attore Su Se Stesso, trans. E. Pavoledo. Roma: Biblioteca Universale Laterza.

Watson, I., 1993. Towards a Third Theatre: Eugenio Barba and the Odin Teatret. London and New York: Routledge.

\section{Websites}

Contemporary-dance, 2013. http://www.contemporary-dance.org/francoisdelsarte.html [Accessed 19 November 2013]. 